\title{
Identifikasi Phanerochaete chrysosporium Yang Diiradiasi Sinar Gamma dengan Marka RAPD
}

\section{Identification of Phanerochaete chrysosporium Irradiated Gamma Ray with RAPD Marker}

\author{
Dadang Sudrajat, Nana Mulyana dan Rika Heryani \\ Pusat Aplikasi Isotop dan Radiasi, BATAN \\ Jl. Lebak Bulus Raya No. 48, Jakarta Selatan 12440 \\ E-mail : dadangs61@batan.go.id
}

\begin{abstract}
ABSTRAK
Phanerochaete chrysosporium merupakan jamur paling potensial yang berperan dalam proses delignifikasi karena menghasilkan enzim lignin peroksidase (LiP) dan mangan peroksidase $(\mathrm{MnP})$. Untuk meningkatkan kemampuan daya lignnolitiknya dilakukan perbaikan genetiknya dengan iradiasi sinar gamma. Informasi tentang perubahan genetik akibat iradiasi pada jamur Phanerochaete chrysosporium sangat diperlukan dalam rangka meningkatkan kemampuan isolat tersebut untuk proses bioremediasi. Penelitian ini bertujuan mendeteksi mutan jamur $P$. chrysosporium hasil iradiasi sinar gamma pada dosis 250-2000 Gy dengan menggunakan marka Random Amplified Polymorphic DNA (RAPD). Tiga oligonukleotida primer $R A P D$ digunakan untuk mengamplifikasi genom DNA. Hasil penelitian menunjukkan bahwa dosis iradiasi berpengaruh pada pertumbuhan $P$. chrysosporium. Nilai $\mathrm{D}_{50}$ pada dosis 1000 Gy. 3 primer, yaitu OPA-1, OPA-4, dan OPD-6 menghasilkan pita-pita polimorfik yang digunakan untuk menganalisis hasil mutasi pada dosis 500; 750; 1000; dan 2000 Gy. Profil DNA-RAPD menunjukkan variasi genetik yang tinggi antara isolat yang diradiasi dan isolat kontrol (0 Gy) dengan formasi 3-5 kluster. Analisis dendrogram menunjukkan nilai koefisien kesamaan (similarity coefficient) antara 0.71-0.91. Hasil ini menunjukkan bahwa $R A P D$ merupakan teknik yang mudah untuk mendeteksi adanya mutasi pada DNA akibat iradiasi.
\end{abstract}

Kata kunci : Phanerochaete chrysosporium, Iradiasi sinar gamma, Marka RAPD

\begin{abstract}
Phanerochaete chrysosporium is the most potent fungus that plays a role in the delignification process because it produces enzyme lignin peroxidase (LiP) and manganese peroxidase (MnP). To enhance the ability of lignolytic activity carried out genetic improvement with gamma ray irradiation. Information on the genetic alteration due to irradiation of the Phanerochaete chrysosporium fungus is indispensable in order to improve the ability of the isolates for the bioremediation process. This study aimed to detect the mutant of $P$. chrysosporium fungus from gamma ray irradiation at doses of 250-2000 Gy using Random Amplified Polymorphic DNA (RAPD) marker. The seven primers of RAPD are used to amplify the DNA genome. The results showed that irradiation dose influenced on $P$. chrysosporium viability. $\mathrm{D}_{50}$ value at 1000 Gy dose. Among the 7 primary, only 3 primers, namely OPA-1, OPA-4, and OPD-6 which yields polymorphic bands to analyze the mutation results at a dose of 500; 750; 1000; and 2000 Gy. The DNA-RAPD profile showed a high genetic variation between the irradiated isolate and the control isolate ( 0 Gy) with the 3-5 cluster formation. Dendrogram analysis showed the coefficient of similarity between $0.60-0.73$. These results revealed that RAPD techniques can be easily used to detection on DNA mutation by irradiation.
\end{abstract}

Keyword : Phanerochaete chrysosporium, Gamma rays irradiation, RAPD marker 


\section{PENDAHULUAN}

Phanerochaete chrysosporium merupakan mikroorganisme ligninolitik paling efisien, namun jamur ini juga dapat menghasilkan enzim protease, kuinon reduktase dan selulase. Jamur ini merupakan mikroorganisme bersel banyak, hidup secara aerobik, non fotosintetik kemoheterotrof, dan termasuk eukariotik. Menggunakan senyawa organik sebagai substrat dan berproduksi secara aseksual dengan spora, kebutuhan metabolisma mereka sama seperti bakteri namun membutuhkan lebih sedikit nitrogen dan dapat tumbuh dan berkembang biak pada $\mathrm{pH}$ rendah. Ukuran jamur lebih besar dari bakteri tapi karakteristik pengendapannya buruk. Oleh karena jamur ini tidak disukai dalam proses activated sludge. Temperature optimum yang mendukung pertumbuhan jamur ini adalah $39 \mathrm{C}$, dengan $\mathrm{pH}$ antara 4-5. Karena mikroorganisme ini termasuk aerobik, maka aktivitas biologisnya juga dipengaruhi oleh konsentrasi oksigen terlarut dalam media [1].

Jamur $P$. chrysosporium memproduksi enzim oksida ekstraseluler yang dapat mendegradasi polimer aromatik kompleks di alam yaitu lignin. Enzim tersebut mengandung peroksidase, lignin peroksidase (LiP) dan Mangan peroksidase (MnP). Enzim pengoksidasi ini menyebabkan oksidasi 1 elektron pada senyawa aromatic dalam lignin. Kation radikal yang dihasilkan mudah dipengaruhi untuk oksidasi selanjutnya dengan adanya $\mathrm{O}_{2}$. Sistem ligninolitik ini sifatnya nonselektif sehingga senyawa aromatic yang lain juga dapat dioksidasi dan dibiodegradasi oleh jamur ini. Contohnya Pentachlorophenol (PCP), dioxins, polycyclic aromatic hydrocarbon ( $\mathrm{PAH})$ dan zat warna azo (Azo dye) [2].

Berdasarkan penelitian yang dilakukan oleh M. Saritha et.al [3], Phanerochaete chrysosporium mempunyai kemampuan mendegradasi lignin sebanyak $81,4 \%$ dan selulosa sekitar $22,3 \%$ dengan waktu inkubasi selama 30 hari.

Aplikasi RAPD dalam analisis keragaman genetik dan identifikasi kapang telah banyak dilakukan seperti pada Aspergillus niger [4] dan Trichoderma sp [5]. Sedangkan analisis molekuler Phanerochaete chrysosporium akibat iradiasi sinar gamma belum pernah dilakukan.

Penelitian ini bertujuan untuk mengidentifikasi polimorfisme DNA jamur $P$. chrysosporium setelah diiradiasi sinar gamma pada dengan menggunakan marka Random Amplified Polymorphic DNA (RAPD). Mutan jamur ini dapat dideteksi melalui profil $R A P D$ yang dihasilkan berdasarkan amplifikasi $P C R$, dan diharapkan dapat digunakan selain sebagai identitas genotip, juga bisa dimanfaatkan lebih lanjut utuk kegiatan bioproses.

\section{BAHAN DAN METODE}

Bahan-bahan yang digunakan adalah media Potatoes Dextrose Agar - PDA (Difco), Agarose (Invitrogen), Larutan buffer eskstraksi (0.1M Tris$\mathrm{HCl}, \mathrm{pH} 8 ; 2.5 \mathrm{M} \mathrm{NaCl} ; 3,5 \% \mathrm{CTAB})$, larutan bufer TE(10mM Tris-HCl pH 8, $1 \mathrm{mM}$ EDTA), Larutan bufer TBE (Tris-Borate-EDTA), Proteinase-K $\quad(20 \mathrm{mg} / \mathrm{ml})($ Invitrogen$), \quad$ larutan RNAse A (Sigma), Larutan PCI (phenol:chloroform: isoamylalcohol (25:24:1), Larutan chloroform-isoamylalcohol (24:1), isopropanol (Merck), ethanol absolut (Merck), dNTP mix (Invitrogen), enzim Taq DNA polymerase (Qiagen), Oligonucleotide primer (Invitrogen). Peralatan yang digunakan antara lain, Mini Gel DNA Electrophoresis (BIORAD), Alat PCR model Mastercycler Gradient (EffendorfGermany), Pipet mikro (Gilson-USA), UV Transilluminator (Vilber Lourmat-France), Alat pemanas/waterbath (OHAEUS), Microcentrifuge (Sorvall, USA), Vortex (Kimax), Neraca Analitik (Acculab BL 210), dan peralatan gelas.

\section{Iradiasi jamur}

Isolat jamur yang digunakan dalam penelitian ini adalah Phanerochete chrysosporium dari koleksi kelompok Lingkungan PAIR-BATAN. Isolat jamur yang telah diremajakan diinokulasikan pada medium Potatoes Dextrose Agar (PDA) dalam cawan petri dan diinkubasi selama 3 hari pada suhu kamar. Biakan berumur 3 hari tersebut kemudian diiradiasi sinar Gamma dalam Iradiator Gamma Cell 220-Upgraded di Pusat Aplikasi Isotop Radiasi - BATAN, Pasar Jumat Jakarta dengan laju dosis 4,3 kGy/jam. Dosis iradiasi yang digunakan adalah $0 \mathrm{kGy}$ (kontrol, tanpa iradiasi); 250 Gy; 500 Gy; 750 Gy; 1000 Gy; 1500; dan 2000 Gy. 


\section{Seleksi jamur hasil iradiasi}

Isolat Phanerochete chrysosporium hasil iradiasi ditumbuhkan dalam $25 \mathrm{ml}$ medium cair $P D B$ selama 7 hari dalam kondisi goyang pada suhu $30^{\circ} \mathrm{C}$. Spora yang sudah diiradiasi kemudian ditanam dalam medium padat PDA untuk dilakukan untuk menentukan jumlah koloni yang bertahan hidup setelah 3 hari.

\section{Penyiapan inokulum hasil iradiasi}

Jamur hasil iradiasi ditumbuhkan dalam 50 $\mathrm{ml}$ medium cair $P D B$ selama 7 hari dalam kondisi goyang pada suhu $30^{\circ} \mathrm{C}$. Pada akhir inkubasi, dilakukan ekstraksi DNA dari miselia sel.

\section{Ekstraksi DNA jamur iradiasi}

Isolasi dan ekstraksi DNA dari miselia Phanerochaete chrysosporium menggunakan metode Iti-Gontia [6]. Miselia dari isolat kapang $\left(\begin{array}{lll} \pm & 200 & \mathrm{~g}\end{array}\right)$ dimasukkan kedalam tabung mikrosentrifuse steril dan ditambahkan $800 \mu 1$ larutan bufer ekstraksi dan $150 \quad \mu$ l larutan proteinase $\mathrm{K}(20 \mathrm{mg} / \mathrm{ml})$. Campuran divortex selama 5 menit, kemudian diinkunbasi dalam waterbath pada suhu $60^{\circ} \mathrm{C}$, selama 30 menit. Campuran disentrifuse $10.000 \mathrm{rpm}$ selama 10 menit pada suhu kamar, supernatan dipindahkan pada tabung sentrifuse baru dan ditambahkan volume sama larutan phenol: khloroform : isoamilalkohol (25:24:1) dan divortex. Campuran disentrifuse $10.000 \mathrm{rpm}$ selama 10 menit pada suhu kamar. Supernatan dipindahkan lagi pada tabung sentrifuse steril baru dan ditambahkan volume sama larutan khloroform : isoamilalkohol (24:1) dan divorteks sperti perlakuan diatas. Supernatan dipindahkan pada tabung sentrifuse steril baru dan ditambahkan volume sama larutan isopropanol dingin dan divorteks. Campuran disentrifuse $13.000 \mathrm{rpm}$ selama 15 menit sampai terbentuk endapan DNA didasar tabung. Pelet DNA dicuci dengan $800 \mu \mathrm{l}$ etanol $70 \%$. Pelet DNA dikeringkan dalam desikator. Dan dilarutkan dalam $100 \mu 1$ larutan TE bufer. DNA divisualisasi dengan elektroforesis gel agarosa $0.8 \%$ dalam bufer Larutan bufer TBE (Tris-Borate-EDTA) dengan pewarna etidium bromida $\left(0.5 \mu \mathrm{g} \mathrm{mL} L^{-1}\right)$. Elektroforesis DNA dilakukan pada $100 \mathrm{~V}$ selama 45 menit dan DNA diamati dengan UV Transilluminator.

\section{Analisis random amplified polymorphism DNA (RAPD) kapang iradiasi}

Hasil ekstraksi DNA diamplifikasi dengan teknik Polymerase Chain Reaction (PCR) menggunakan 3 macam primer dengan urutan basa seperti telihat pada Tabel 1 .

Tabel 1. Urutan Basa Primer untuk Amplifikasi DNA Phanerochaete chrysosporium iradiasi.

\begin{tabular}{ll}
\hline Nama Primer & Urutan Basa (5'-------- 3') \\
\hline 1. OPA-1 & CAGGCCCTTC \\
2.OPA-4 & AATCGGGCTG \\
3. OPD-6 & GGGGTCTTGA \\
\hline
\end{tabular}

Analisis RAPD dilakukan dengan menggunakan random primer dari Life Technologies- Invitrogen (Tabel 1), Reaksi PCR menggunakan HotStarTaq ${ }^{\mathrm{TM}}$ Master Mix kit (Qiagen, Clifton Hill, Vic.). Volume reaksi yang digunakan dalam analisa RAPD ini adalah $25 \mu 1$ yang terdiri dari cetakan DNA (dengan konsentrasi 10ng), $12.5 \mu \mathrm{L}$ HotStarTaq ${ }^{\mathrm{TM}}$ Master Mix $(1 \times$ buffer PCR, 1.25 Unit Taq polymerase, $20 \mathrm{mM}$ untuk tiap-tiap dNTP), $\mathrm{MgCl} 2(1.5 \mathrm{mM})$ dan primer (5 pmol). Program siklus termal adalah : aktivasi awal pada $95^{\circ} \mathrm{C}$ selama 15 menit diikuti dengan 40 siklus yang terdiri dari 1 menit pada suhu $94{ }^{\circ} \mathrm{C}$, 1 menit pada $36^{\circ} \mathrm{C}$, dan 2 menit pada $72^{\circ} \mathrm{C}$. Selanjutnya diikuti dengan 1 siklus pemanjangan final pada $72^{\circ} \mathrm{C}$ selama 10 menit. Hasil amplifikasi diamati dengan elektroforesis pada $1 \%$ gel agarose dalam buffer TBE dan diwarnai dengan etidium bromide.

\section{Skoring dan analisis data}

Pengamatan DNA hasil elektroforesis dapat diamati dengan menggunakan UV transluminator. DNA kemudian di beri skor berdasarkan jarak tempuhnya (bp) dan diberi skor yaitu 0 apabila tidak ada yang muncul dan 1 untuk kenampakan yang ada. Data biner yang diperoleh dianalisis dengan menggunakan MVSP versi 2.0. Modul SIMQUAL digunakan dalam menggeneralisirkan matriks similaritas Koefesien Jaccard. Matriks jarak yang diperoleh digunakan analisis pengelompokkan. Hasil pengelompokan kemudian digunakan dalam menyusun dendogram dengan metode unweighted pair-group method with arithmetic mean (UPGMA). [7]. 


\section{HASIL DAN PEMBAHASAN}

Kurva pertumbuhan Phanerochete chrysosporium yang diiradiasi pada dosis $0-2000$ Gy terlihat pada Gambar 1. Iradiasi sinar gamma berpengaruh terhadap pertumbuhan isolat jamur Phanerochate chrysosporium. Mulai dari dosis iradiasi 250; 500; 750; 1000; 1500; dan 2000 Gy terjadi penurunan jumlah koloni masing -masing sebesar 9,$5 ; 28.6 ; 39,0 ; 59,0 ; 73,5$; dan $84.1 \%$.
Semua primer yang digunakan menghasilkan pita polimorfik, primer OPA-1 mempunyai pita monomorfik pada ukuran 2150; 2100; 1300; 900; 700; dan 500 bp (Tabel 2). Pita polimorfik terdapat pada isolat hasil iradiasi 250; 500; 750; 1000; 1500; dan 2000 Gy masing -masing berjumlah $1,1,4,1,3$, dan 4 buah, sedangkan pita yang tidak muncul (delesi) terdapat pada isolat hasil iradiasi 250; 500; 750; 1000; 1500; dan 2000 Gy dengan ukuran 2100 bp .

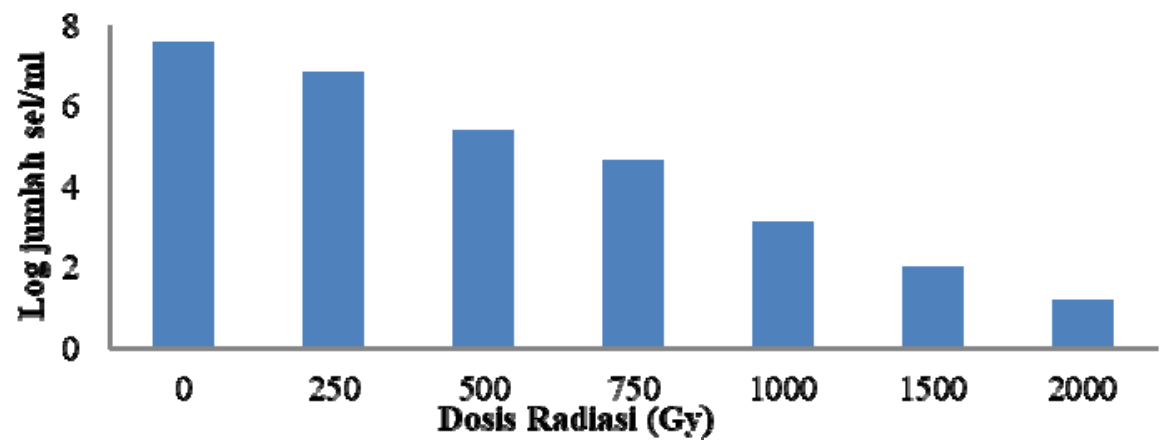

Gambar 1. Pengaruh dosis iradiasi sinar gamma terhadap pertumbuhan jamur Phanerochete chrysosporium.

Dari hasil penelitian yang dilakukan sebelummya pada isolat Aspergillus niger [8], menyatakan bahwa dosis iradiasi yang dapat menurunkan pertumbuhan sel sebesar 50- 90\% adalah dosis optimum yang dapat menyebabkan mutasi radiasi pada kapang tersebut. Dari hasil penelitian ini kemungkinan dosis optimum terjadinya mutasi isolat Phanerochaete chrysosporium adalah antara dosis 1000 dan 2000 Gy. Nilai $\mathrm{D}_{50}$ pada dosis radiasi $1000 \mathrm{~Gy}$.

Isolat jamur Phanerochaete chrysosporium (Pc) yang diiradiasi pada dosis 0-2000 Gy, terlihat mampu tumbuh pada medium cair PDB setelah inkubasi pada $30^{\circ} \mathrm{C}$ selama 7 hari. Hasil pengamatan secara makroskopis Phanerochaete chrysosporium, meliputi warna dan bentuk miselia, berdasarkan morfologinya tidak menunjukkan adanya perbedaan karakteristik antara kontrol dan Pc iradiasi.

Hasil analisis perubahan genetik dari isolat Phanerochaete chrysosporium radiasi menggunakan primer OPA-1: OPA-4: dan OPD-6 pada reaksi PCR terlihat pola pita DNA yang berbeda mulai dari dosis iradiasi pada setiap dosis radiasi yang digunakan (Gambar 2, 4 dan 6).

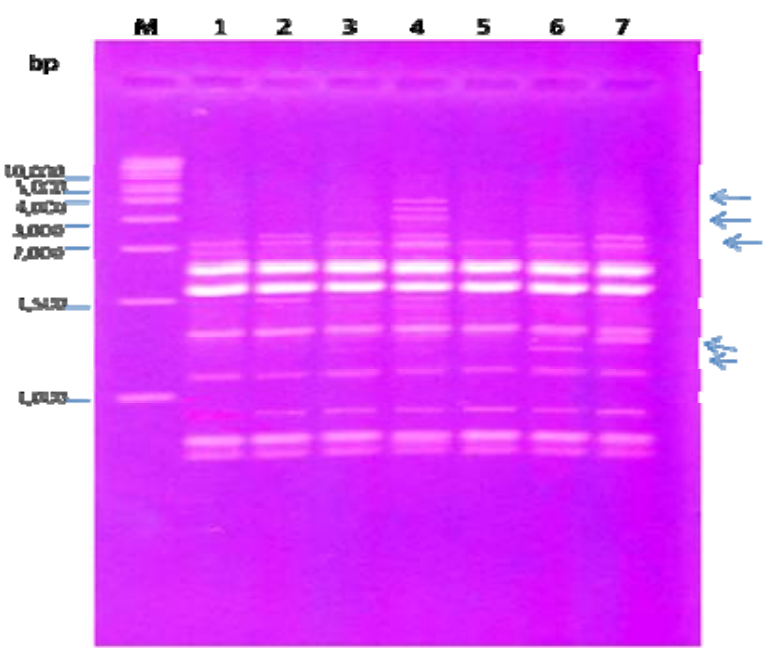

Gambar 2. Pola pita DNA Phanerochaete chrysosporium iradiasi dengan menggunakan primer OPA-1 : Lajur 1 (0 Gy), Lajur 2 ( 250 Gy), Lajur 3 (500Gy), Lajur 4 (750 Gy), Lajur 5 (1000 Gy), Lajur 6 (1500 Gy), Lajur 7 (2000 Gy), M (Marker, 1Kb DNA ladder), --> (pita polimorfik). 
Tabel 2. Pita monomorfik dan polimorfik dari Phanerochaete chrysosporium iradiasi dengan primer OPA-1

\begin{tabular}{|c|c|c|c|c|c|c|c|}
\hline \multirow{2}{*}{$\begin{array}{c}\text { Ukuran } \\
\text { pasangan basa }\end{array}$} & \multicolumn{6}{|c|}{ Dosis Radiasi (Gy) } & \multirow[b]{2}{*}{2000} \\
\hline & 0 (kontrol) & 250 & 500 & 750 & 1000 & 1500 & \\
\hline 5000 & & & & $---*$ & & & ---* \\
\hline 4000 & & & & $---*$ & $---*$ & ---* & ---* \\
\hline 3500 & & & & $---*$ & & & \\
\hline 2200 & & ---* & ---* & $---*$ & & ---* & ---* \\
\hline 2150 & --- & --- & --- & --- & --- & --- & --- \\
\hline 2100 & --- & $*$ & $*$ & $*$ & $*$ & $*$ & $*$ \\
\hline 1300 & --- & --- & --- & --- & --- & --- & --- \\
\hline 1250 & & & & & & & ---* \\
\hline 1200 & & & & & & ---* & \\
\hline 1000 & --- & --- & --- & --- & --- & --- & --- \\
\hline 900 & --- & --- & --- & --- & --- & --- & --- \\
\hline 700 & --- & --- & --- & --- & --- & --- & --- \\
\hline 500 & --- & --- & --- & --- & --- & --- & --- \\
\hline
\end{tabular}

Keterangan :

--- : pita yang muncul pada gel agarose

---*: pita polimorfik.

* : pita yang tidak muncul (delesi).

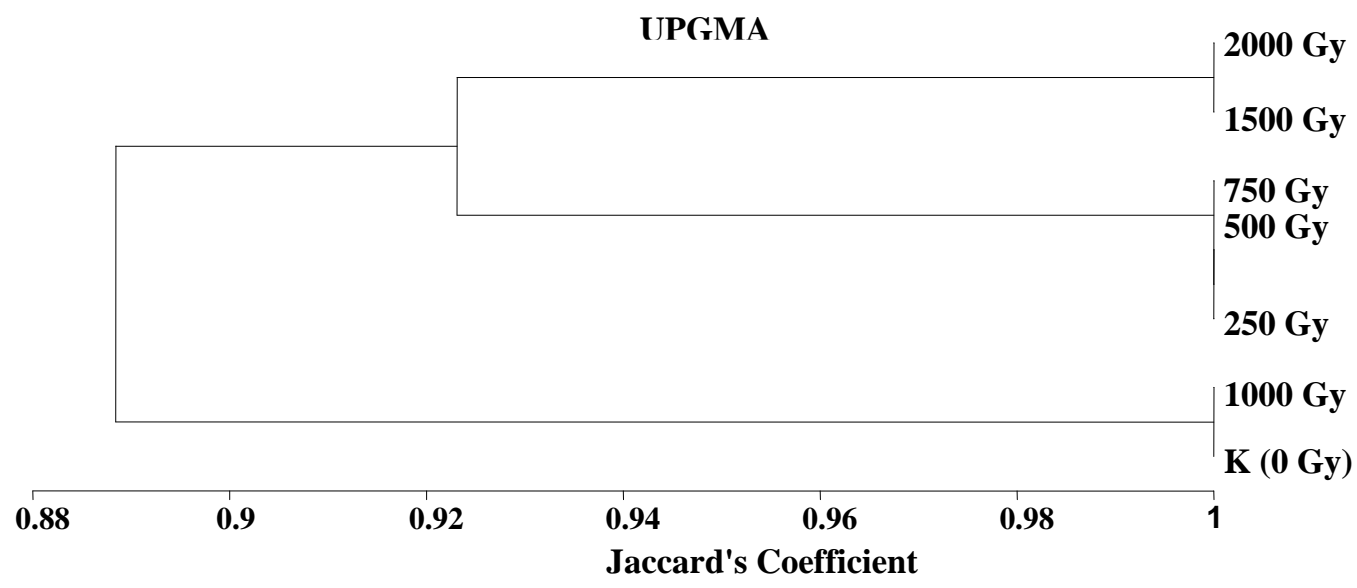

Gambar 3. Dendrogram hubungan similaritas genetik isolat Phanerochaete chrysosporium iradiasi dengan menggunakan primer OPA1.

Hasil analisis pengelompokkan (cluster analysis) RAPD-PCR dari primer OPA-1 menggunakan metode Unweight Pair Group Method Average (UPGMA) berupa dendrogram pada tingkat kesamaan genetik $89 \%$, isolat Phanerochaete chrysosporium iradiasi membentuk 3 kelompok. Kelompok A terdiri dari isolat $\mathrm{K}(0)$ dan $1000 \mathrm{~Gy}$. Kelompok B terdiri dari isolat 250; 500; dan $750 \mathrm{~Gy}$. Kelompok C terdiri dari 1500 dan 2000 Gy (Gambar 3).
Hasil uji keragaman genetik dari isolat Phanerochaete chrysosporium iradiasi berdasarkan amplifikasi RAPD-PCR menggunakan primer OPA-4 juga menunjukkan pola pita DNA yang berbeda mulai dari dosis iradiasi 250; 500; 750; 1000; 1500; dan 2000 Gy. Primer OPA-4 mempunyai pita monomorfik pada ukuran $1800 ; 1700 ; 1400 ; 1300 ; 1250 ; 1000 ; 900$; 700 dan 500 bp. Pita polimorfik terdapat pada isolat hasil iradiasi 500 Gy berjumlah 1 buah. Sedangkan pita yang tidak muncul (delesi) terjadi 
pada isolat hasil radiasi 250; 375 ; dan 750 Gy masing-masing berjumlah 2 buah. Seperti yang ditunjukkan pada Gambar 4 dan Tabel 3.

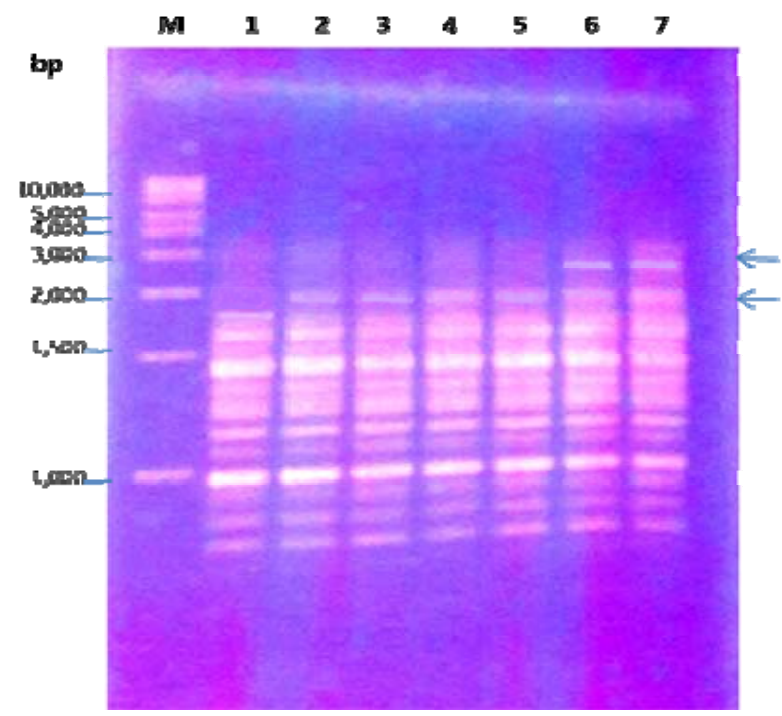

Gambar 4. Pola pita DNA Phanerochaete chrysosporium iradiasi dengan menggunakan primer OPA-4 : Lajur 1 (0 Gy), Lajur 2 (250 Gy), Lajur 3 (500Gy), Lajur 4 (750 Gy), Lajur 5 (1000 Gy), Lajur 6 (1500 Gy), Lajur 7 (2000 Gy), M (Marker, 1Kb DNA ladder), --> (pita polimorfik).
Hasil analisis pengelompokkan (cluster analysis) RAPD-PCR dari primer OPA-4 menggunakan metode Unweight Pair Group Method Average (UPGMA) berupa dendrogram pada tingkat kesamaan genetik $82 \%$, isolat Phanerochaete chrysosporium iradiasi membentuk 3 kelompok. Kelompok A terdiri dari isolat $\mathrm{K}(0)$. Kelompok B terdiri dari isolat 250, 500, 750, dan 1000 Gy. Kelompok C terdiri dari isolat 1500 dan 2000 Gy (Gambar 5).

Primer OPD-6 memiliki pita monomorfik pada ukuran 3000; 1800; 1400; 1300; 1200; 1100; 1000; dan 800 bp. Sedangkan pita polimorfik terdapat pada isolat hasil iradiasi $250 \mathrm{~Gy}$; 500; $750 ; 1000 ; 1500$; dan 2000 Gy masing-masing berjumlah $1,1,1,2$ dan 2 buah, seperti ditunjukkan Gambar 6 dan Tabel 4. Hasil analisis pengelompokkan (cluster analysis) RAPD-PCR dari primer OPD-6 menggunakan metode Unweight Pair Group Method Average (UPGMA) berupa dendrogram pada tingkat kesamaan genetik $89 \%$, isolat Phanerochaete chrysosporium iradiasi membentuk 3 kelompok.

Kelompok A terdiri dari isolat $\mathrm{K}(0)$ dan $1000 \mathrm{~Gy}$. Kelompok B terdiri dari isolat 250, 500, dan 750 Gy. Kelompok C terdiri dari isolat 1500 dan 2000 Gy (Gambar 7).

Tabel 3. Pita monomorfik dan polimorfik dari Phanerochaete chrysosporium iradiasi dengan primer OPA-4

\begin{tabular}{|c|c|c|c|c|c|c|c|}
\hline \multirow{2}{*}{$\begin{array}{c}\text { Ukuran } \\
\text { pasangan basa }\end{array}$} & \multicolumn{6}{|c|}{ Dosis Radiasi (Gy) } & \multirow[b]{2}{*}{2000} \\
\hline & 0 (kontrol) & 250 & 500 & 750 & 1000 & 1500 & \\
\hline 3000 & & & & & & ----* & ---* \\
\hline 2000 & & $---*$ & ---* & $---*$ & $---*$ & $---*$ & $---*$ \\
\hline 1800 & --- & & & & & & \\
\hline 1700 & --- & --- & --- & --- & --- & --- & --- \\
\hline 1400 & --- & --- & --- & --- & --- & --- & --- \\
\hline 1300 & --- & --- & --- & --- & --- & --- & --- \\
\hline 1250 & --- & --- & --- & --- & --- & --- & --- \\
\hline 1100 & --- & --- & --- & --- & --- & --- & --- \\
\hline 1250 & --- & --- & --- & --- & --- & --- & --- \\
\hline 1000 & --- & --- & --- & --- & --- & --- & --- \\
\hline 900 & --- & --- & --- & --- & --- & --- & --- \\
\hline 700 & --- & --- & --- & --- & --- & --- & --- \\
\hline 500 & --- & --- & --- & --- & --- & --- & --- \\
\hline
\end{tabular}

Keterangan :

--- : pita yang muncul pada gel agarose

---*: pita polimorfik.

* : pita yang tidak muncul (delesi). 


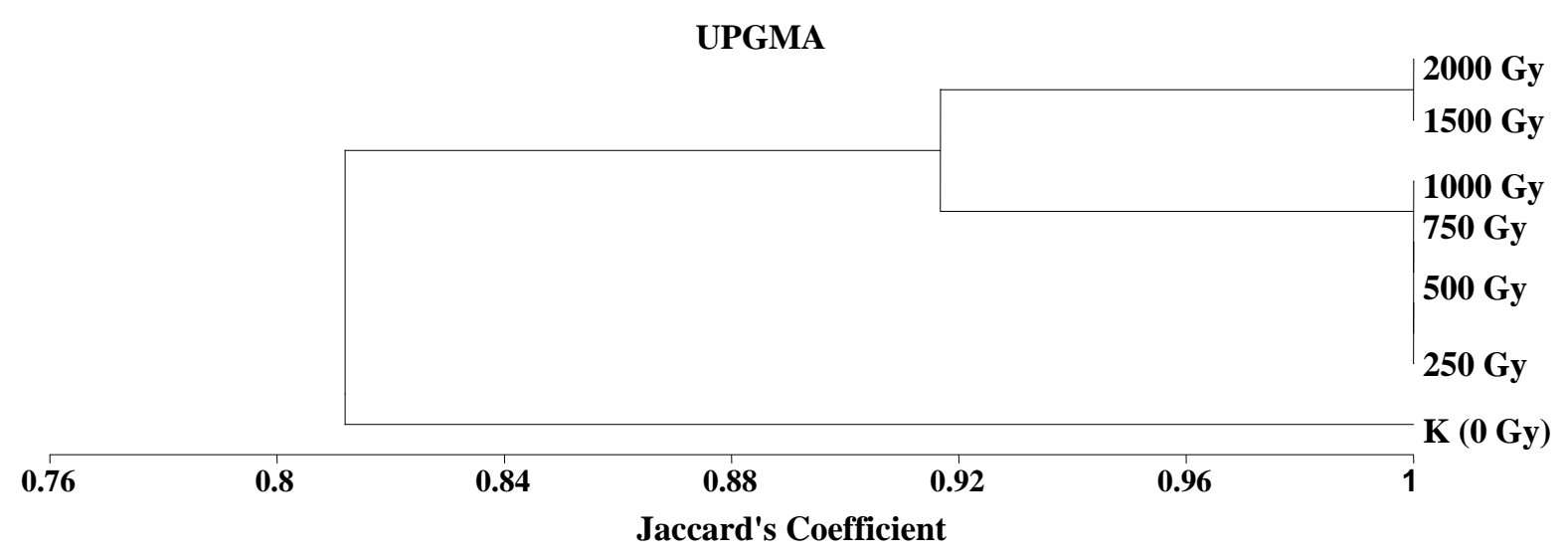

Gambar 5. Dendrogram hubungan similaritas genetik isolat Phanerochaete chrysosporium iradiasi dengan menggunakan primer OPA4.

Tabel. 4. Pita monomorfik dan polimorfik dari Phanerochaete chrysosporium iradiasi dengan primer OPD-6.

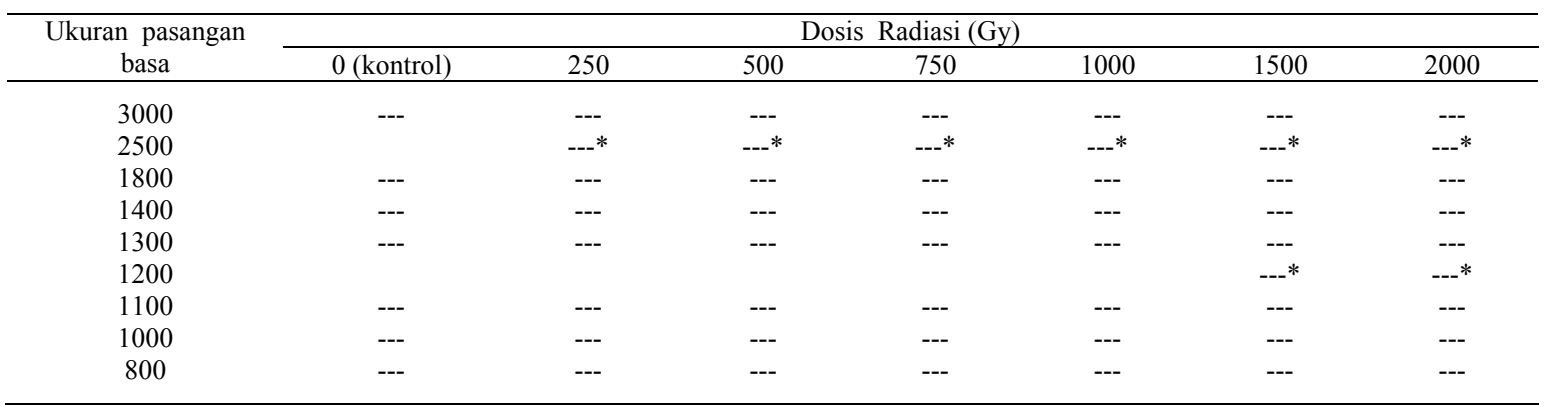

Keterangan :

--- : pita yang muncul pada gel agarose

---*: pita polimorfik.

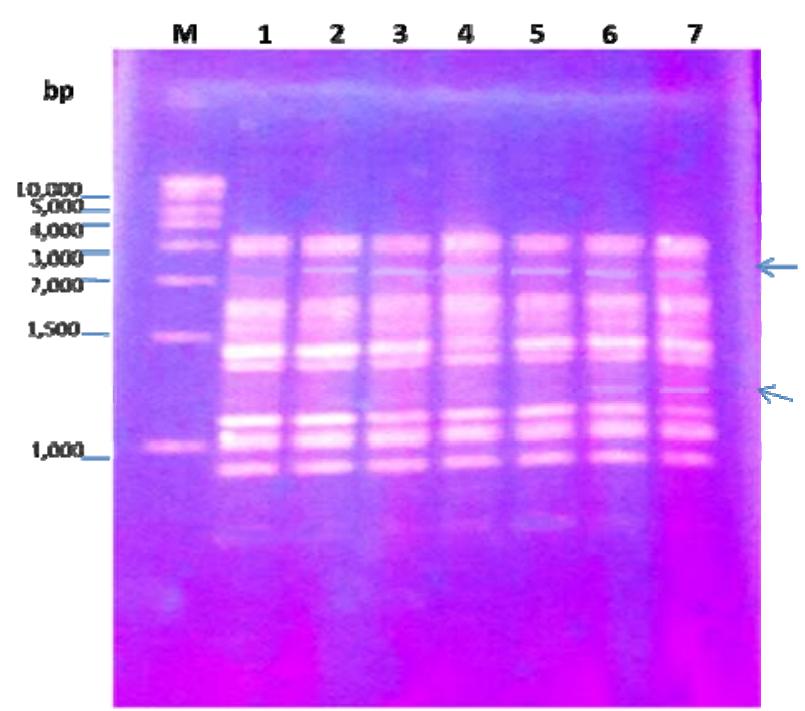

Gambar 6. Pola pita DNA Phanerochaete chrysosporium iradiasi dengan menggunakan primer OPD-6 : Lajur 1 (0 Gy), Lajur 2 (250 Gy), Lajur 3 (500Gy), Lajur 4 (750 Gy), Lajur 5 (1000 Gy), Lajur 6 (1500 Gy), Lajur 7 (2000 Gy), M (Marker, $1 \mathrm{~Kb} \quad \mathrm{DNA}$ ladder), $\quad-->\quad$ (pita polimorfik).
Dari hasil pengamatan diatas, maka mutasi radiasi dari isolat jamur Phanerochaete chrysosporium terjadi mulai dari dosis iradiasi 500 - 2000 Gy. Suatu genotip dikategorikan sebagai mutan apabila profil DNA-nya berbeda dari profil DNA kontrol dan profil tersebut konsisten berbeda pada semua primer yang digunakan. Perbedaan ini disebabkan oleh perbedaan urutan nukleotida pada keempat primer yang digunakan, sehingga menyebabkan perlekatan primer di sepanjang DNA genom sampel juga berbeda. Pita yang dihasilkan setelah amplifikasi DNA dengan PCR sangat bergantung pada bagaimana primer mengenal daerah komplemennya pada cetakan (template) DNA yang digunakan. Semakin banyak situs penempelan dari primer yang digunakan, maka semakin banyak jumlah pita DNA yang dihasilkan [9]. Isolat mutan $P$. chrysosporium hasil iradiasi dosis 600 Gy sudah di gunakan pada proses delignifikasi lignoselulosa. Peningkatan aktivitas enzim Lignin Peroksidase (LiP) sebesar 25,65\% dibandingkan dengan kontrol. [10]. Hasil 


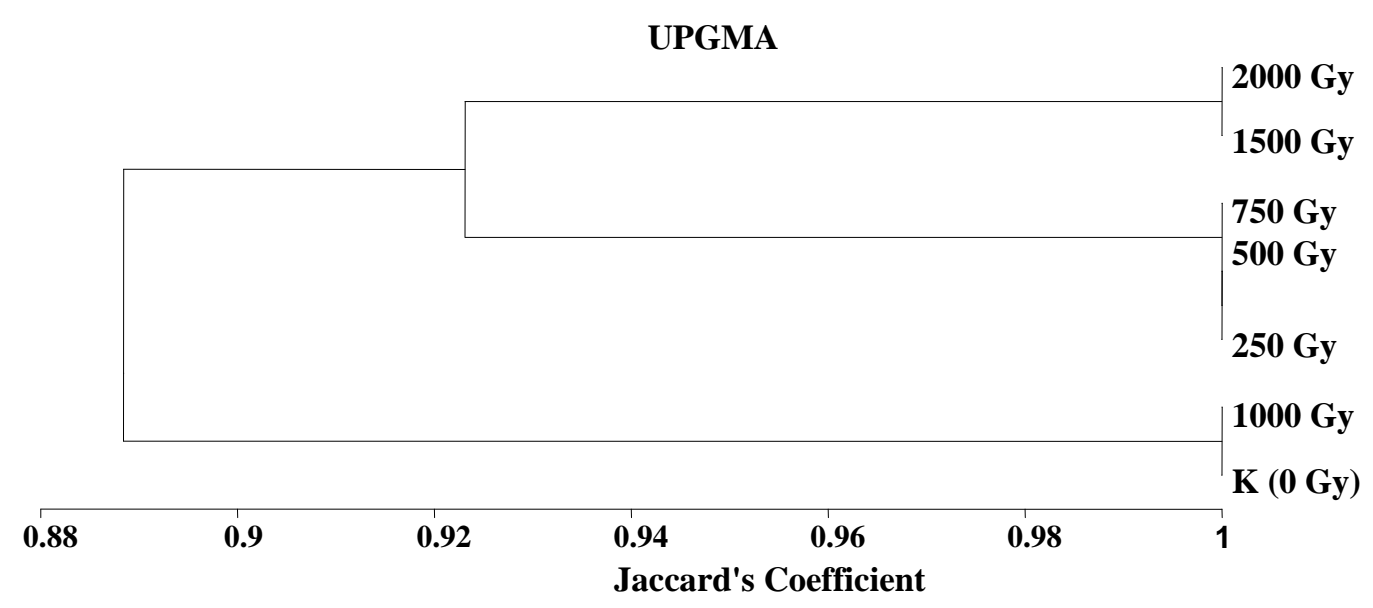

Gambar 7. Dendrogram hubungan similaritas genetik isolat Phanerochaete chrysosporium iradiasi dengan menggunakan primer OPD6.

penelitian lain pada mutan isolat Aspergillus niger hasil seleksi setelah diiradiasi sinar gamma pada dosis 1,4 kGy menunjukkan peningkatan produksi enzim endoxylanase sebesar $125 \%$ dibandingkan dengan kontrol [11].

\section{KESIMPULAN}

Isolat Phanerochaete chrysosporium iradiasi tidak menunjukkan adanya perbedaan karakteristik morfologis dibandingkan dengan isolat kontrol (0 Gy). Dosis iradiasi sinar gamma berpengaruh terhadap viabilitas $P$. chrysosporium dengan nilai $\mathrm{D}_{50}$ pada dosis iradiasi 1000 Gy. Dari hasil analisis molekuler DNA menggunakan marka $R A P D-P C R$, maka mutasi radiasi dari isolat kapang Phanerochaete chrysosporium terjadi mulai dari dosis iradiasi $500-2000 \mathrm{~Gy}$.

\section{UCAPAN TERIMA KASIH}

Penulis mengucapkan terima kasih pada Sdr. Arief Adhari dan Bpk. Marwadi yang telah membantu dalam menyelesaikan penelitian ini.

\section{DAFTAR PUSTAKA}

[1] Deepak Singh and Shulin Chen. The whiterot fungus Phanerochaete chrysosporium:conditions for the production of lignin-degrading enzymes.
Applied Microbiology and Biotechnology, vol. 81, no. 3, pp. 399417, 2008.

[2] A.P. Thakkar, V.S. Dhamankar, and B.P. Kapadnis. Biocatalytic decolourisation of molasses by Phanerochaete chrysosporium. Bioresources Technology. vol. 97, no. 12 Elsevier, pp. 1377-1381, 2006.

[3] M. Saritha, Anju Arora, and Lata. Biological Pretreatment of Lignocellulosic Substrates for Enhanced Delignification and Enzymatic Digestibility. Indian. Journal of Microbiology, vol. 52, no. 2, pp. 122-130, 2012.

[4] Azza A. Mostafa. Effect of gamma irradiation on Aspergillus niger DNA and production of cellulases enzymes. $J$. Am. Sci, vol. 10, no. 5, ISSN : 15451003, pp. 152-160, 2014.

[5] A. Ranga Rani, S. Khayum Ahammed and A.K. Patibanda. Genetic Diversity of Trichoderma sp. from Rhizosphere Regions of Different Cropping Systems using RAPD Markers. Int. J. Curr. Microbiol. App. Sci., vol. 6, no. 7, pp. 1618-1624, 2017.

[6] Iti-Gontia-Mishra, Niraj Tripathy, and Sharad Tiwwari. A simple and rapid DNA extraction protocol for filamentous 
fungi efficient for molecular studies. Indian Journal of Biotechnology, vol. 13, pp. 536-539, 2014.

[7] Kovach, WL. MVSP- A multivariate statistical package for windows, Ver.3.2, Kovach Computing Services, Pentraeth, Wales, U.K. 2010.

[8] Muhammad, A.Z, Samreen, R, and Threema, I., Effect of gamma Irradiation on Aspergillus niger enhanced production of glucose oxidase. Pak.J. Bio., vol. 44, no. 5, pp. 1575-1580, 2012.

[9] Atienzar, F.A., Venier P, Jha. AN, Depledge, M.H,. Evaluation of the RAPD assay for detection of DNA damage and mutations. Mut Res. 521, 151-163, 2002.
[10] Tri Retno, DL., Nana Mulyana, Nurhasni, dan Uswatun Hasanah. Pengaruh radiasi sinar gamma terhadap kemampuan degradasi lignin Phanerochaete chrysosporium dan Ganoderma lucidum. Jurnal Sains dan Teknologi Nuklir Indonesia, vol. 17, no. 1, pp. 21-35, 2016.

[11] C. Ottenheim, K.A.Werner, W. Zimmermann, and Jin Chuan Wu. Improved endoxylanase production and colony morphology of Aspergillus niger DSM 26641 by $\gamma$-ray induced mutagenesis. Biochemical Engineering Journal, 94, 9-14, 2015. 
Jurnal Ilmiah Aplikasi Isotop dan Radiasi

A Scientific Journal for The Applications of Isotopes and Radiation

p ISSN 1907-0322

Vol. 14 No. 1 Juni 2018

e ISSN 2527-6433 